論文

$$
\begin{gathered}
\text { 기내 서비스 환경에 대한 승무원의 인식이 동기부여 및 서비스 지향성을 } \\
\text { 매개로 하여 서비스 제공행동에 미치는 영향에 관한 연구 } \\
\text { 최덕진*, 김문선**, 김기웅***,박성식**** }
\end{gathered}
$$

\title{
A Study on Cabin Crew's Perception of Cabin Servicescape to Their Service Performance through Motivation and Direction
}

\author{
Duk Jin Choi *, Mun Sun Kim **, Kee Woong Kim*, Sung Sik Park****
}

\begin{abstract}
In-flight service, depending on the perceptions of service satisfaction because ever turns into a variable, which enables service providers the flexibility of a variable in the end flight service to suit your needs to providing comprehensive and proactive services of the crew will be motivated. In addition, the service provider's motivation to work in a confined space on board the flight service characteristics in-flight service will be a major impact on the environment. This service-oriented environment, in-flight service and motivation in order to verify the impact on services in Cape factors as independent variables and the dependent variable service-oriented multi- regression analysis was performed. As a result, the motivation of the crew and the crew of the service-oriented, with a voluntary service crew services dependent variable parameters that affect the behavior of the acts. Services and service-oriented motivation Cape factors significantly influence both the irradiated while the impact on voluntary service and results verification service aesthetics, cleanliness, and physical service environment, only the voluntary services of the crew a positive effect on that the effects were investigated.
\end{abstract}

Key Words : In-flight services(기내서비스), service environment(서비스환경), motivation(동 기), Cabin(기내), behavioral(행동)

$$
\text { I. 서 론 }
$$

21세기 들어 서비스는 단지 서비스 산업에만 국한되지 않고 거의 모든 산업분야를 아우르는 성장 동력이며 경쟁력의 원천으로 자리 잡고 있

2013년 10월 18일 접수 2013년 12월 18일 심사완료 논문심사일 (2013.10.25, 1차), (2013.12.04, 2차)

* 한국항공대학교 경영학과 박사과정 수료

** 아시아나항공 캐빈서비스팀 사무장

*** 한국항공대학교 경영학과 교수

**** 한국항공대학교 항공경영학과 박사과정 수료 연락저자, E-mail : airportthinker@gmail.com 경기도 고양시 덕양구 항공대학로 76
다. 그리고 항공사의 서비스 중에서 승객의 운송, 안전, 식음료 및 면세품 판매 등 상식적으로 알 수 있는 서비스 활동의 거의 전 분야를 제한된 공간 즉 서비스 최접점인 기내(Cabin)에서 제공 하는 승무원의 기내 서비스야 말로 서비스 업계 의 선두 주자라 할 수 있는 항공 산업에서도 가 장 중요한 업무 중 하나라고 말할 수 있을 것이 다. 2000년대 이후 국제여객 수요 증대에 따른 항공 산업의 급속한 성장과 더불어 항공 서비스 분야의 수많은 선행연구가 이루어진 바 있다. 하 지만 대부분의 기내서비스 관련 선행 연구문헌들 은 고객의 만족도, 중요도 혹은 서비스 만족도와 서비스 중요도의 차이에 대한 승객의 인식을 서 
비스 품질로 정의하여 서비스 품질 증대에 대한 노력에만 집중하였다. 물론 항공사 서비스의 최 고봉이 기내에서 제공되는 승무원의 고객 서비스 이므로 기내서비스 품질 개선 혹은 품질 증대에 대한 항공 실무자 혹은 관련 분야 연구자들의 노 력은 아무리 지나쳐도 중요하지 않다고 말할 수 없을 것이다.

하지만 양대 국적항공사에서 승무원 관리와 기 내 서비스와 관련된 전문가들은 서비스 환경 (Servicecape)과 실제로 여객이 인식하는 기내서 비스 품질과의 차이가 있음을 주지하여 왔다. 따 라서 본 연구에서 서비스 환경에 대한 승객들의 인식이 승무원들이 서비스를 제공하는 데 어떠한 영향을 미치는 지에 대한 실증연구를 진행하고자 하였다. 이를 위해 첫째, 서비스 환경을 과거 연 구문헌들을 통해 분석하고 기내라는 특수한 공간 속에서 서비스 환경이 구성하는 다양한 속성들을 정의하고자 하였다. 둘째 이러한 서비스 환경 속 성들에 대해 승무원들이 어떻게 인식하는 지 그 리고 승무원들의 인식이 승무원들의 서비스 지향 성, 서비스 동기부여 및 서비스 제공의도에 어떠 한 영향을 미치는 지 수집된 설문결과를 통해 실 증하고자 하였다. 마지막으로 서비스 환경을 구 성하는 속성, 서비스 지향성, 서비스 동기부여 및 서비스 제공의도들 간의 인과관계를 살펴보고 이 러한 인과관계 속에서 향후 탑승여객들의 기내서 비스 만족도 증진을 위해서 국적항공사가 어떻게 서비스 품질과 서비스 환경을 개선해 나가야 하 는 지에 대한 관리자적 및 경영학적 시사점을 제 시하고자 하였다.

특히 과거 서비스케이프 연구문헌에서 다루어 지지 않았던 “서비스 매뉴얼의 기능성”이라는 측 면까지 확대하여 서비스 매뉴얼의 융통성에 대한 승무원들의 인식과 행동이 서비스 동기부여 및 지향성에 어떠한 영향을 미치는 지 살펴보고자 하였다.

\section{II. 본 론}

\section{1 서비스 인카운터(Service Encounter)}

여러 산업분야에 있어서 서비스의 중요성이 나날이 부각되면서 서비스 기업들이 지속적으로 성장하고 있지만 그와 동시에 고객들의 서비스 경험에 대한 짜증과 불만의 목소리도 커지도 있 다 (Koepp 1987). 대부분의 서비스 인카운터는 개별 고객의 관점으로부터의 서비스라 할 수 있
다. 과거 폭넓게 이뤄졌던 서비스 경험 및 서비 스 만족 등과 같은 서비스 관련된 연구들은 대체 적으로 각각의 개념이 인간의 인식을 기반으로 하고 있기 때문에 복합성을 띄고 있음을 언급하 고 있다. 하지만 그중 가장 중요한 연구 대상인 고객의 서비스 만족도는 직접적이고 즉각적으로 각 개별 서비스 인카운터에 의해 영향을 받는다 는 것이다. (Parasuraman, Zeithmal, and Berry 1985; Shostack 1984, 1987; Solomon et al. 1985; Surprenant and Solomon 1987).

개별 서비스 인카운터에 대한 관리는 서비스 기업의 조직구조뿐만 아니라 인문, 사회 및 문화 등 폭 넓은 시각으로 고려되어야 한다. 이러한 관리를 통해 서비스 제공자는 서비스 품질에 대 한 고객의 인식에 긍정적인 영향을 미칠 수 있 다. Shostack(1984)이 제시한 서비스 인카운터 평 가모델은 고객이 직접적으로 서비스를 받는 순간 인식할 수 있는 인적, 물적 서비스 및 기타 모든 유-무형의 등 서비스 회사에서 접할 수 있는 모 든 요소들을 총망라 하고 있다. 이에 대해 Normann(1991)은 '고객과 기업의 서비스가 만나 는 순간이라고 서비스 인카운터 모델을 정의하 기도 했다.

결국 두 연구자 모두 서비스 기업이 서비스를 제공할 때 고객이 서비스를 직접 만나는 접점을 의미하는 것이다. 고객들의 서비스 인카운터 만 족은 제품이나 서비스를 경험하기 전 그에 대한 기대치와 경험치를 비교하면서 결정되어진다. 기 대치가 실제 경험한 것보다 크다면 결과는 불만 족이 되고, 기대치를 충족하거나 이를 뛰어넘을 경우 만족이란 결과를 얻게 된다. “고객만족"은 서비스에 대한 고객의 일반적인 인식 성향과 매 우 밀접한 관계가 있지만, 서비스에 만족한다고 해서 그것이 고객의 보편적 인식이라고는 할 수 없다.

고객의 사고방식으로부터 만족을 구분하는 핵 심은 사고방식은 매우 보편적인 반면 만족의 평 가는 개인적은 거래처럼 매우 주관적이라는 인식 에 직졀된다. 이와 유사한 또 다른 이론으로 만 족이 인식된 품질로부터 구분될 수 있는 연구도 있다. Parasuraman, Zeithmal and Berry는 "인식 된 서비스 품질"이란 개별 고객이 서비스 기업에 대해 갖는 일반적인 생각과 유사하다 (Zeithmal 1988). 서비스 인카운터 평가모델은 고객의 속성 을 전형적인 만족 범주(Satisfaction Paradigm) 내에 포함하고 있다. 고객 속성이란 자신들의 행 동, 타인의 행동 혹은 그들이 관찰하고 있는 현 상에 대하여 어떠한 것이 원인인가에 대해 인지 
하는 것을 의미한다.

\section{2 서비스 환경 (Servicescape)}

과거에는 조직 내에서 환경 조성이 어떻게 이 루어지는지에 대한 연구가 많지 않았다(Backer, 1981). 환경의 조성 및 관리는 봉급수준, 승진, 복리후생, 관리감독관계 등과 같이 여타 조직에 서 직원들에게 동기부여를 해주는 일반적인 변수 들과 비교해볼 때 그 실효성이 별로 없는 것처럼 여겨졌었다. 이와 마찬가지로 일반적인 소비자에 대해 생각해볼 때에도, 서비스가 이뤄지는 곳의 환경을 조성하는 것보다 가격, 광고, 특별 홍보활 동 등과 같은 변수들을 활용하는 것이 더욱 그들 을 유인하거나 회사의 서비스로부터 만족감을 느 끼도록 하는데 유용한 것으로 여겨졌었고, 과거 에는 서비스 만족에 대한 연구에 있어서 대부분 이에 바탕을 두어 정의를 내렸었다. 어떻게 업 무 - 서비스 환경을 조성하느냐 또한 내부 조직의 목표나 외부 마케팅 목표 달성에 있어서 긍정적 이거나 부정적인 영향을 미칠 수 있다. 환경 조 성 또한 여타 조직 변수나 마케팅 변수들과 마찬 가지로 해당업의 성격이나 고객의 서비스 경험에 그 기반을 두고 있다. 이에 대해서 더욱 발전된 입장으로, 물리적 서비스 환경(Physical Service Environment) 조성의 중요성을 강조한 선행 연 구들이 있다. 이 선행연구들에 따르면 물리적 서 비스 환경은 외부고객인 고객들은 물론 내부고객 인 직원들까지도 종종 회사의 시설과 서비스를 이용하기 때문에 물리적 서비스 환경은 고객의 서비스 만족도와 내부직원의 서비스 제공 동기부 여에 더욱 중요한 요소가 될 수 있다. 하지만, 모 든 서비스 관련 회사나 산업은 그 업무 환경 요 건이 동일하지 않기 때문에 직면하고 있는 서비 스 환경을 디자인 하는데 있어서 각각에 맞는 또 다른 시각이 필요하다(Schmenner 1986).

Bitner(1992)는 서비스 환경의 유형을 세 가지 로 구분하여 정의한 바 있다. 각 서비스 환경 유 형은 이용객이 스스로 서비스를 이용하는 셀프서 비스(Self-Service), 직원과 이용객이 상호작용을 해야 하는 대인 서비스(Interpersonal Service), 그 리고 원거리 서비스(Remote Service) 즉, 이용객 의 접근 없이 서비스 직원에 의해서 제공되는 서 비스로 구분되어 있다. 먼저 구분을 보면 서비스 환경에서 누가(소비자, 직원, 혹은 둘 다) 행동을 취하는지를 나타내고 있다. 각각을 살펴보면 "Self-Service"는 직원이 제공하는 서비스가 매우 적고 소비자의 역할이 상대적으로 높은 서비스를
말한다. 이와 반대되는 유형으로는 "Remote Service" 가 있는데, 이는 서비스 환경에서 소비 자의 관여가 드물거나 아예 없는 형태의 서비스 를 말한다. 앞서 설명한 두 가지의 중간 형태로 볼 수 있는 "Interpersonal Services"는 소비자와 직원 모두가 서비스 환경에서 일정한 역할을 가 지는 서비스를 말한다. 소비자와 직원의 관여도 와 관련된 상대적 수준은 누구의 니즈(needs)가 환경 설계에서 반영되어야 하는지에 따라 결정된 다. Interpersonal Services 환경에서는 물리적 환 경이 지나는 효과와 소비자들과 직원들 사이의 사회적 상호작용의 질에 대한 특별한 고려가 필 요하다.

서비스 환경의 이론적 출발점은 바로 환경심리 학이었다. 환경심리학은 물리적 또는 사회적 자 극이 직접적으로 한 개인의 정서적 상태에 영향 을 미침으로써 행동에 영향을 주게 된다는 이론 이다. 그 이후 서비스 환경에 대한 연구는 환경 심리학적인 측면으로 주로 연구되었다(Baker et al., 1994). 예를 들어, Baker et al.(1992)는 Meharabian \& Russell의 모델(M-R 모델)을 토대 로 환경적 단서를 비디오테이프 시뮬레이션기법 을 통해 4 가지로 조작한 후, 조사대상자들의 유 쾌함, 환기, 구매의도에 대한 공조환경의 단서(조 명과 음악)와 사회적 환경의 단서(직원의 수와 친절성)를 조사하였다. 연구결과 유쾌함과 환기 가 증가하면 구매의도가 증가하고, 점포환경에 의한 정서적 상태가 고객의 구매의도에 영향을 미친다는 사실을 검증하여 $\mathrm{M}-\mathrm{R}$ 모델의 논리를 더욱 확고히 지지하였다. 리테일 업계에 있어서 매장 관리자들은 환기적인 환경을 창출함으로써 수익성을 더 높일 수 있다고 주장했다.

\section{3 서비스 지향성}

Beatty \& Schneider(1981)은 “서비스 지향성은 경영진의 경영 철학과 경영 스타일에 내포된 인 식"이라고 정의 내린 바 있다. 이들은 서비스 지 향성을 크게 두 가지로 구분하였다. 첫째는 서비 스 기업의 업무절차, 시스템 및 내부직원 관리를 중요시 하는 '조직 중심적 서비스 지향성'이다. 둘째는 고객과의 유연하고 개방적인 커뮤니케이 션을 통해 고객과의 서비스 관계를 더욱 중시하 는 '고객 중심적 서비스 지향성'이다. 서비스 지 향성 지수로 알려진 SOI (Service Orientation Index)는 서비스기업의 서비스 지향정도를 평가 할 수 있는 기준이다. 서비스 지향성은 서비스 기업의 목표를 달성을 위하여 내부고객인 직원들 
간의 상호 태도 및 관계의 총체적 집합으로 표현 될 수 있다.

반면에 기업의 서비스 지향성은 고객 서비스의 범주 내에서 시장 정보에 반응하는 기업의 마케 팅 활동이라고도 할 수 있다 (유정남 등, 2000). 서비스 지향성을 서비스 기업이 시장정보에 전략 적으로 대응하면서 경쟁 기업과 차별화되는 높은 품질의 서비스를 고객에게 제공하기 위한 전략적 이고 집합적인 조직 활동의 정도라고 평가했다. 다시 말해서 상기 선행 연구들을 토대로 서비스 지향성은 서비스기업이 최고의 서비스 품질을 가 장 최우선으로 한다는 믿음이며 고객들이 자사의 서비스 품질을 가장 우월하게 인식한다는 것이 경쟁우위의 원천이라고 믿는 것이라고 정리할 수 있다.

\section{4 동기부여}

동기유발에 관한 이론은 각 학자들의 강조점에 따라 다른 관점을 가지고 형성되어 왔다. 일반적 으로 이 이론이 강조하는 부분에 따라 동기유발 이론은 크게 내용이론, 과정이론 및 강화이론으 로 나눌 수 있다. 동기유발에 관한 내용이론은 동기유발 과정 중 첫 단계인 동인, 욕구, 동기 등 에 초점을 둔 이론이다. 즉 어떠한 요인이 동기 유발의 원인인가를 밝히는데 있다.

예컨대 임금, 작업시간, 작업조건, 자율성, 책임 부여 등을 동기유발 요인으로 간주하는 경우이 다. 내용이론의 가장 전통적인 이론으로는 미국 의 심리학자이면서 철학자이기도 한 메슬로의 동 기이론(Maslow's Motivation Theory, 1943)과 동 기부여를 유발하는 욕구 5단계(Maslow's hierarchy of Needs)를 들 수 있다.

첫째로, 욕구계층이론은 그림과 같이 인간의 내부에는 다섯 가지의 욕구가 있음을 강조한다. 다섯 가지 욕구는 생리적, 안전, 사회적, 존경 및 자아실현 욕구이다. 생리적 욕구는 인간의 가장 기본적인 욕구로, 개인의 생리적 균형을 유지하 는 데 필요한 욕구를 말한다. 의, 식, 주 및 성적 욕구 등이 이에 속한다. 생리적 욕구 (Psysio-logical needs)는 욕구계층에 있어서 가장 기초적인 위치를 차지한다. 조직 차원에서 이 욕 구는 구성원 자신의 생리적 욕구를 충족시킬 수 있는 경제적 보상에 대한 관심에서 나타난다. 안 전욕구는 육체적, 정서적 안정(security)에 대한 욕구를 말한다. 조직 차원에서는 신체적 보호, 안 정된 직업, 생계에 대한 보장 등의 관심으로 나 타난다. 사회적 욕구는 주로 대인관계에서 나타
나는 욕구로 타인과의 교제, 친분, 소속감과 같이 정을 주고받고 서로 소고되기를 원하는 욕구이 다. 조직 차원에서는 다른 구성원에 의해 수용되 고 집단에 소속되기를 원하는 행동에서 나타난 다. 존경 욕구는 타인으로부터 인정을 받거나 존 경을 받고 싶어 하는 심리적 욕구를 말한다. 이 욕구는 자존심, 자율 및 성취감과 같은 내부적 요인과 지위 신분, 안정 및 관심의 대상이 되고 싶어 하는 욕구와 같은 외부적 요인으로 나눌 수 있다. 조직 차원에서는 개인의 신분이나 지위에 대한 관심에서 나타난다. 자아실현 욕구는 자신 이 갖고 있는 잠재적 능력을 최대로 발휘하고 싶 어 하는 욕구로 성장 욕구, 자기완성 욕구 등이 해당한다. 조직 차원에서는 자율성, 보람이 있는 직무, 능력개발, 성취적 행동에 대한 관심에서 나 타난다.

즉 가장 기본적인 생리적 옥구가 충족되면 안 전 욕구를 원하게 되고, 이어서 사회적 욕구,존경 욕구, 자아실현 욕구의 순으로 상위 수준의 욕구 를 원하게 된다. 일반적으로 사람들은 $85 \%$ 의 생 리적 욕구, $70 \%$ 의 안전 욕구, $50 \%$ 사회적 욕 구, $40 \%$ 의 존경 욕구, $10 \%$ 의 자아실현 욕구를 충 족하고 있는 것으로 알려져 있다.

\section{3. 연구 방법}

\section{1 연구 설계}

본 연구에서는 $\mathrm{A}$-항공사에 근무하는 객실승무 원들을 대상으로 기내 서비스케이프 평가속성이 승무원의 동기부여, 서비스 지향성 및 서비스 제 공 행동에 미치는 영향을 살펴보고자 한다. 기내 서비스케이프 평가속성인 물리적 환경, 심미성, 기내기능성, 매뉴얼 기능성 및 청결성 등을 독립 변수로 설정하였다. 매개변수로는 승무원들의 동 기부여, 서비스 지향성 및 자발적 고객 서비스로 설정하였다. 마지막으로 종속변수로는 서비스 제 공행동으로 설정하여 아래와 같은 연구모형을 가 정하였다.

실증분석을 위하여 A-항공사에 근무하는 객실 승무원들을 대상으로 설문을 수행하였다. 연구 조사기간은 약 4 주에 걸쳐 승무원들에게 자가 보 고식 설문지 작성을 요청하였다. 총 250 부를 배 포하여 총 202부를 회수하였다. 연구조사의 결과 를 분석하는데 있어서 SPSS 21.0을 사용하였으 며, 측정도구의 내적 타당성을 확인하기 위해 Cronbach's a 계수를 이용하였다. 탐색적 요인분 
석을 위해 주성분 분석법을 이용하였으며, 요인 회전에 있어서는 요인들 간의 상호 독립성을 검 정하는데 유용한 직교회전(Varimax)법을 이용하 였다. 가설검증 방법으로는 탐색적 요인분석을 통해 생성된 요인점수들을 변수화 하여 이를 바 탕으로 다중회귀분석을 실시하였다.

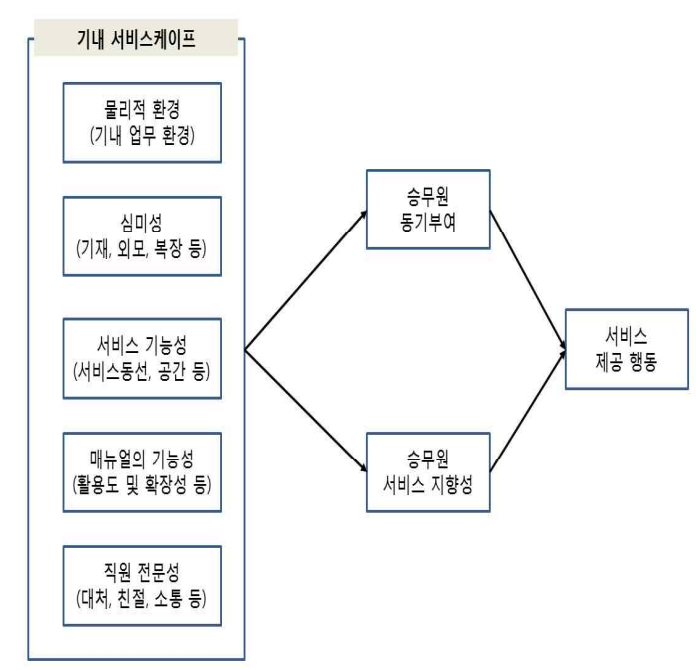

Fig 1 연구 모형

Table 1 설문항목의 구성

\begin{tabular}{c|c|c}
\hline 구분 & 설문항목 & 비 고 \\
\hline 인구통계학적요인 & $\mid-1 \sim 1-6$ & 명목형 \\
\cline { 1 - 2 } 서비스환경평가속성 & $\mathrm{II}-1 \sim \mathrm{II}-24$ & \multirow{2}{*}{ 연 속형 } \\
\cline { 1 - 2 } 서비스 동기부여 & $\mathrm{III-1} \sim \mathrm{II}-5$ & (7점 리커트 \\
\cline { 1 - 2 } 서비스 지향성 & $\mathrm{IV}-1 \sim \mathrm{IV}-4$ & 척도) \\
\cline { 1 - 2 } 서비스 제공행동 & $\mathrm{V}-1 \sim \mathrm{V}-5$ & \\
\hline
\end{tabular}

\section{2 연구 가설}

국적사인 A-항공사에 근무하는 객실승무원들 을 대상으로 기내 서비스케이프 평가속성이 승무 원의 동기부여, 서비스 지향성 및 서비스 제공 행동에 미치는 영향에 대한 실증연구의 가설들을 독립변수, 매개변수 및 종속변수에 따라 다음과 같이 설정하였다.

<기내 서비스케이프가 승무원의 동기부여에 미치는 영항> 가설 1-1. 물리적 서비스 환경은 승무원의 동기 부여에 정(+)의 영향을 미친다.

가설 1-2. 서비스 심미성은 승무원의 동기부여에 정 $(+)$ 의 영향을 미친다.
가설 1-3. 서비스 기능성은 승무원의 동기부여에 정 $(+)$ 의 영향을 미친다.

가설 1-4. 매뉴얼 기능성은 승무원의 동기부여에 정 $(+)$ 의 영향을 미친다.

가설 1-5. 서비스 청결성은 승무원의 동기부여에 정 $(+)$ 의 영향을 미친다.

$<$ 기내 서비스케이프가 승무원 서비스 지향성에 미치는 영항>

가설 2-1. 물리적 서비스 환경은 승무원의 서비스 지향성에 정(+)의 영향을 미친다.

가설 2-2. 서비스 심미성은 승무원의 서비스 지향성 에 정(+)의 영향을 미친다.

가설 2-3. 서비스 기능성은 승무원의 서비스 지향성 에 정(+)의 영향을 미친다.

가설 2-4. 매뉴얼 기능성은 승무원의 서비스 지향성 에 정(+)의 영향을 미친다.

가설 2-5. 서비스 청결성은 승무원의 서비스 지향성 에 정 $(+)$ 의 영향을 미친다.

<매개변수가 종속변수에 미치는 영향>

가설 3-1. 승무원의 동기부여는 승무원의 서비 스 제공행동에 정 $(+)$ 의 영향을 미친 다.

가설 3-2. 승무원의 서비스 지향성은 서비스 제 공행동에 정 $(+)$ 의 영향을 미친다.

\section{3 분석 결과}

\subsection{1 인구통계학적 특성}

설문조사의 인구 통계학적 특성은 다음과 같 다. 성별에 따라서는 여성이 $90.6 \%$ (183명), 남성 이 $9.4 \%(19$ 명 $)$ 로 여성 응답자의 비율이 남성응답 자 보다 약 10 배 정도 많았으며, 연령대별로는 20대 39.1\% (79명), 30대 49\%(99명), 40대 $11.9 \%(24$ 명)으로 20 대와 30 대에 응답자들이 편중 되는 경향을 나타냈다.

직급의 경우 $\mathrm{CC}$ (사원)가 104 명 $(51.5 \%)$ 로 약 절 반정도를 차지하였고 $\mathrm{AP}$ (대리)가 55 명 $(27.2 \%)$, $\mathrm{PS}$ (과장)가 30 명(14.9\%), $\mathrm{SP}$ (차장)가 11 명(5.4\%) 그리고 $\mathrm{CP}$ (부장)가 2 명 $(1.0 \%)$ 로 나타났다. 결혼에 대한 응답의 경우 응답자의 절반이 넘는 124 명 $(61.4 \%)$ 가 미혼이라고 응답하였다.

\subsection{2 측정도구의 타당성}

일반적으로 탐색적 연구 분야에서는 Cronbach's a 값이 .60이상이 되면 측정치도 문 
제가 없다고 제시하고 있고, 기초분야에서는 .80 , 나아가 중요한 결정이 요구되는 응용연구 분야에 서는 .90 이상이면 된다고 주장한다. 아울러 측정 하고자 하는 개념이 설문지를 구성하는 각 항목 들에 의해 적절하게 측정되었는지 구성개념 타당 도를 알아보기 위해 <표 2>와 같이 변수들에 대 한 요인분석(Factor Analysis)을 실시하였다.

Table 2 구성개념별 요인분석 결과

\begin{tabular}{|c|c|c|c|c|}
\hline \multicolumn{5}{|c|}{ 구성개념 } \\
\hline \multirow{3}{*}{\multicolumn{2}{|c|}{$\begin{array}{l}\text { 서비스 } \\
\text { 기능성 }\end{array}$}} & \multicolumn{3}{|c|}{ 서비스 기능성2 } \\
\hline & & \multicolumn{3}{|c|}{ 서비스 기능성1 } \\
\hline & & \multicolumn{3}{|c|}{ 서비스 기능성3 } \\
\hline \multirow{2}{*}{\multicolumn{2}{|c|}{$\begin{array}{c}\text { 제외된 } \\
\text { 설문항목 }\end{array}$}} & \multicolumn{3}{|c|}{ 심미성 2} \\
\hline & & \multicolumn{3}{|c|}{ 심미성 1} \\
\hline \multirow{5}{*}{\multicolumn{2}{|c|}{$\begin{array}{l}\text { 서비스 } \\
\text { 청결성 }\end{array}$}} & \multicolumn{3}{|c|}{ 청결성1 } \\
\hline & & \multicolumn{3}{|c|}{ 청결성3 } \\
\hline & & \multicolumn{3}{|c|}{ 청결성2 } \\
\hline & & \multicolumn{3}{|c|}{ 청결성5 } \\
\hline & & \multicolumn{3}{|c|}{ 청결성4 } \\
\hline \multirow{4}{*}{\multicolumn{2}{|c|}{$\begin{array}{l}\text { 서비스 } \\
\text { 심미성 }\end{array}$}} & \multicolumn{3}{|c|}{ 심미성4 } \\
\hline & & \multicolumn{3}{|c|}{ 심미성3 } \\
\hline & & \multicolumn{3}{|c|}{ 심미성6 } \\
\hline & & \multicolumn{3}{|c|}{ 심미성5 } \\
\hline \multirow{6}{*}{\multicolumn{2}{|c|}{$\begin{array}{c}\text { 물리적 } \\
\text { 서비스 환경 }\end{array}$}} & \multicolumn{3}{|c|}{ 물리적 환경1 } \\
\hline & & \multicolumn{3}{|c|}{ 물리적 환경2 } \\
\hline & & \multicolumn{3}{|c|}{ 물리적 환경3 } \\
\hline & & \multicolumn{3}{|c|}{ 물리적 환경4 } \\
\hline & & \multicolumn{3}{|c|}{ 물리적 환경5 } \\
\hline & & & 리적 환궁 & \\
\hline & & & 어얼 기능 & \\
\hline & & & 후얼 기능 & \\
\hline & & & 우얼 기능 & \\
\hline & & & 얼 기능 & \\
\hline 요인1 & 요인2 & 요인3 & 요인4 & 요인5 \\
\hline .776 & .304 & .209 & .131 & .285 \\
\hline .774 & .291 & .196 & .076 & .316 \\
\hline .681 & .239 & .149 & .243 & .426 \\
\hline .396 & .301 & .309 & .210 & .069 \\
\hline .225 & .218 & .390 & .249 & .232 \\
\hline .145 & .854 & .198 & .008 & .200 \\
\hline .232 & .795 & .202 & .188 & .105 \\
\hline .214 & .793 & .223 & .187 & .266 \\
\hline .253 & .646 & .106 & .333 & .183 \\
\hline .311 & .572 & .109 & .282 & .200 \\
\hline .090 & 106 & .837 & .085 & .146 \\
\hline .294 & .163 & .710 & .136 & .057 \\
\hline .161 & .266 & .698 & .011 & .206 \\
\hline .418 & .165 & .589 & .209 & .179 \\
\hline .034 & .132 & .258 & .500 & .088 \\
\hline .139 & .148 & .280 & .751 & .036 \\
\hline .241 & .099 & .067 & .740 & .265 \\
\hline
\end{tabular}

\begin{tabular}{l|l|l|l|l}
\hline .166 & .281 & .018 & .711 & .191 \\
\hline .066 & .073 & .393 & .640 & .358 \\
\hline .252 & .137 & .220 & .591 & .157 \\
\hline .143 & .242 & .240 & .179 & .818 \\
\hline .341 & .231 & .094 & .186 & .785 \\
\hline .239 & .140 & .229 & .305 & .720 \\
\hline .444 & .304 & .126 & .194 & .652 \\
\hline 11.20 & 1.82 & 1.73 & 1.35 & 1.05 \\
\hline 46.70 & 54.27 & 61.48 & 67.13 & 71.53 \\
\hline \multicolumn{5}{|c}{3364.93} \\
\hline \multicolumn{5}{|c}{.000} \\
\hline
\end{tabular}

탐색적 요인분석은 주성분분석을 이용하였으며 요인회전에 있어서는 직교회전(Varimax)법을 이 용하였고 고유치(Eigen Value) 1.0 이상인 요인들 을 추출하도록 지정하였다. 기내 서비스케이프 항목에 대한 요인분석에서 고유치가 1.0 이상인 총 5 개의 요인이 추출되었는데 요인 1 은 서비스 기능성, 요인2는 서비스 청결성, 요인3은 서비스 심미성, 요인4는 물리적 서비스 환경. 요인5는 서 비스 매뉴얼로 구성되었다. 또한 변수들 간의 상 관관계가 다른 변수에 의해 설명되는 정도를 나 타내는 KMO (Kaiser -Meyer-Olkin)의 값은 0.929 로 나타나 1에 근접하므로 요인분석을 위한 변수선정이 바람직함을 알 수 있다. 그리고 바트 레트(Bartlett)의 구형성검정치가 3364.93이고, 유 의확률 값이 .000 이므로 요인분석 모형이 매우 적합하다는 것을 나타내고 있다. 공통성이 0.4 이 하인 낮은 변수는 요인분석에서 제외하였는데 심 미성에 대한 설문항목 1 과 설문항목 2 가 공통성 이 0.4 미만으로 요인으로 추출되지 않아 요인분 석 및 다중회귀분석에서 분석의 대상으로 제외하 였다.

\subsection{3 가설 검증}

가설검증 방법으로 각 변수들 간의 인과관계를 알아보기 위하여 요인분석 결과 중의 하나인 요 인점수를 사용하여 다중회귀분석을 실시하였다. 기내 서비스케이프 항목이 승무원의 동기부여에 미치는 영향력을 검증하기 위하여 상기 가설에 나오는 서비스케이프 요인 5개를 독립변수로 하 고 승무원의 동기부여를 종속변수로 하는 다중회 귀분석을 실시하였다.

전체 모형의 적합도를 보여주는 F-값이 50.113 $(\mathrm{p}=.000)$ 으로 매우 유의하게 나타났으므로 다중 회귀분석을 위한 모델 설정은 매우 적합한 것으 로 나타났다. 아울러 5 개의 독립변수들의 서로 
상관을 나타내는 다중공선성 계수들은 각각 $\mathrm{VIF}=1.000$ 이며 Durbin-Watson=1.796을 나타내 고 있어 변수들 간 다중공선성 위험성은 제거된 것을 확인 할 수 있다. 다중회귀분석 결과를 살 펴보면, 5 개의 독립변수들 중에서 4 개의 독립변 수들만이 충성도에 유의한 영향을 미치는 변수로 분석되었다.

Table 3 가설검증 (종속변수 : 동기부여)

\begin{tabular}{|c|c|c|c|c|c|}
\hline $\begin{array}{l}\text { 종솟 } \\
\text { 변수 }\end{array}$ & 독립변수 & Beta & $\begin{array}{l}\text { Std. } \\
\text { Beta }\end{array}$ & $\begin{array}{l}\mathrm{t} \text {-값 } \\
(\mathrm{p}-\text { - ㅏㅐㅄ }\end{array}$ & VIF \\
\hline \multirow{4}{*}{$\begin{array}{l}\text { 동기 } \\
\text { 부여 }\end{array}$} & $\begin{array}{l}\text { 서비스 } \\
\text { 매뉴얼 }\end{array}$ & .427 & .421 & $\begin{array}{l}8.298 \\
(.000)\end{array}$ & 1.00 \\
\hline & $\begin{array}{l}\text { 서비스 } \\
\text { 심미성 }\end{array}$ & .411 & .408 & $\begin{array}{l}8.041 \\
(.000)\end{array}$ & 1.00 \\
\hline & $\begin{array}{l}\text { 물리적 } \\
\text { 서비스 환경 }\end{array}$ & .306 & .302 & $\begin{array}{l}5.945 \\
(.000)\end{array}$ & 1.00 \\
\hline & $\begin{array}{l}\text { 서비스 } \\
\text { 기능성 }\end{array}$ & .275 & .273 & $\begin{array}{l}5.381 \\
(.000)\end{array}$ & 1.00 \\
\hline 종속 & \multicolumn{5}{|c|}{$\begin{array}{l}\mathrm{DW}=1.796, \mathrm{~F}=50.113(\mathrm{p}=.000) \\
\text { Adj } \triangle R^{2}=.560\end{array}$} \\
\hline
\end{tabular}

첫째, 서비스 매뉴얼이 승무원의 동기부여에 대해 표준화 회귀계수 $\beta$ 가 .421로 가장 높은 회 귀계수를 보여주면서 긍정적인 양 $(+)$ 의 계수 값 으로 나타나고 있고, $\mathrm{p}$ 값이 .000로 $95 \%$ 신뢰수준 에서 매우 유의한 값을 나타냈다. 따라서 '기내 서비스케이프 항목 중 서비스 매뉴얼은 승무원의 동기부여에 정(+)의 영향을 미친다' 라는 가설 1-4는 실증 결과 채택되었다.

둘째, 서비스 심미성이 승무원의 동기부여에 대해 표준화 회귀계수 $\beta$ 가 .408로 높은 회귀계수 를 보여주면서 긍정적인 양 $(+)$ 의 계수 값으로 나 타나고 있고, $\mathrm{p}$ 값이 .000로 $95 \%$ 신뢰수준에서 매 우 유의한 값을 나타냈다. 따라서 '기내 서비스케 이프 항목 중 서비스 심미성은 승무원의 동기부 여에 정 $(+)$ 의 영향을 미친다' 라는 가설 1-2는 실 증 결과 채택되었다.

셋째, 물리적 서비스 환경이 승무원의 동기부 여에 대해 표준화 회귀계수 $\beta$ 가 .302로 높은 회 귀계수를 보여주면서 긍정적인 양(+)의 계수 값 으로 나타나고 있고, p값이 .000로 $95 \%$ 신뢰수준 에서 매우 유의한 값을 나타냈다. 따라서 '기내 서비스케이프 항목 중 물리적 서비스 환경은 승 무원의 동기부여에 정(+)의 영향을 미친다' 라는 가설 1-1은 실증 결과 채택되었다.

넷째, 서비스 기능성이 승무원의 동기부여에 대해 표준화 회귀계수 $\beta$ 가 .273으로 높은 회귀계
수를 보여주면서 긍정적인 양(+)의 계수 값으로 나타나고 있고, $\mathrm{p}$ 값이 .000 로 $95 \%$ 신뢰수준에서 매우 유의한 값을 나타냈다. 따라서 '기내 서비스 케이프 항목 중 서비스 기능성은 승무원의 동기 부여에 정 $(+)$ 의 영향을 미친다' 라는 가설 1-3은 실증 결과 채택되었다.

<표 $4>$ 와 같이 기내 서비스케이프 항목이 서 비스 지향성에 미치는 영향력을 검증하기 위하여 서비스케이프 요인 5 개를 독립변수로 하고 서비 스 지향성을 종속변수로 하는 다중회귀분석을 실 시하였다.

Table 4 가설검증 (종속변수 : 서비스지향성)

\begin{tabular}{|c|c|c|c|c|c|}
\hline $\begin{array}{l}\text { 종속 } \\
\text { 변수 }\end{array}$ & 독립변수 & Beta & $\begin{array}{l}\text { Std. } \\
\text { Beta }\end{array}$ & $\begin{array}{c}\mathrm{t} \text {-값 } \\
(\mathrm{p}-\mathrm{y} \text { 값 })\end{array}$ & VIF \\
\hline \multirow{4}{*}{$\begin{array}{l}\text { 서비스 } \\
\text { 지향성 }\end{array}$} & $\begin{array}{l}\text { 서비스 } \\
\text { 매뉴얼 }\end{array}$ & .367 & .366 & $\begin{array}{l}5.813 \\
(.000) \\
\end{array}$ & 1.00 \\
\hline & $\begin{array}{l}\text { 서비스 } \\
\text { 심미성 } \\
\end{array}$ & .217 & .216 & $\begin{array}{l}3.440 \\
(.001) \\
\end{array}$ & 1.00 \\
\hline & $\begin{array}{c}\text { 물리적 } \\
\text { 서비스 환경 }\end{array}$ & .198 & .198 & $\begin{array}{l}3.143 \\
(.002)\end{array}$ & 1.00 \\
\hline & $\begin{array}{l}\text { 서비스 } \\
\text { 기능성 }\end{array}$ & .169 & .168 & $\begin{array}{l}2.676 \\
(.008)\end{array}$ & 1.00 \\
\hline $\begin{array}{l}\text { 종속 } \\
\text { 변수 }\end{array}$ & \multicolumn{5}{|c|}{$\begin{array}{l}\mathrm{DW}=1.485, \mathrm{~F}=14.418(\mathrm{p}=.000) \\
\text { Adj } \triangle R^{2}=.527\end{array}$} \\
\hline
\end{tabular}

본 연구의 연구모형에 따르면 승무원의 서비스 지향성은 궁극적으로 종속변수인 승무원의 서비 스 제공행동에 영향을 미치는 매개변수의 역할을 한다. 전체 모형의 적합도를 보여주는 $\mathrm{F}$-값이 $14.418(\mathrm{p}=.000)$ 로 매우 유의하게 나타났으므로 다 중회귀분석을 위한 모델 설정은 매우 적합한 것 으로 나타났다. 아울러 4 개의 요인들(독립변수들) 의 서로 상관을 나타내는 다중공선성 계수들은 각각 $\mathrm{VIF}=1.000$ 이며 Durbin-Watson $=1.485$ 를 나타내고 있어 변수들 간 다중공선성 위험성은 제거된 것을 확인 할 수 있다. 다중회귀분석 결 과를 살펴보면, 5 개의 독립변수들 중에서 4 개의 독립변수들 모두 서비스 지향성에 유의한 영향을 미치는 변수로 분석되었다.

첫째, 서비스 심미성이 승무원의 서비스 지향 성에 대해 표준화 회귀계수 $\beta$ 가 366 으로 가장 높은 회귀계수를 보여주면서 긍정적인 양 $(+)$ 의 계수 값으로 나타나고 있고, $\mathrm{p}$ 값이 .000 로 $95 \%$ 신뢰수준에서 매우 유의한 값을 나타냈다. 따라 서 '기내 서비스케이프 항목 중 서비스 심미성은 승무원의 서비스 지향성에 정 $(+)$ 의 영향을 미친 다' 라는 가설 2-2는 실증 결과 채택되었다.

둘째, 서비스 청결성이 승무원의 동기부여에 대해 표준화 회귀계수 $\beta$ 가 .216으로 높은 회귀계 
수를 보여주면서 긍정적인 양 $(+)$ 의 계수 값으로 나타나고 있고, $\mathrm{p}$ 값이 .001로 95\% 신뢰수준에서 매우 유의한 값을 나타넸다. 따라서 '기내 서비스 케이프 항목 중 서비스 청결성은 승무원의 서비 스 지향성에 정 $(+)$ 의 영향을 미친다' 라는 가설 2-5는 실증 결과 채택되었다.

셋째, 서비스 매뉴얼이 승무원의 서비스 지향 성에 대해 표준화 회귀계수 $\beta$ 가 .198로 높은 회 귀계수를 보여주면서 긍정적인 양 $(+)$ 의 계수 값 으로 나타나고 있고, $\mathrm{p}$ 값이 .002로 $95 \%$ 신뢰수준 에서 매우 유의한 값을 나타냈다. 따라서 '기내 서비스케이프 항목 중 서비스 매뉴얼은 승무원의 서비스 지향성에 정 $(+)$ 의 영향을 미친다' 라는 가설 2-4는 실증 결과 채택되었다. 마지막으로 물리적 서비스 환경이 승무원의 서비스 지향성에 대해 표준화 회귀계수 $\beta$ 가 .169로 높은 회귀계수 를 보여주면서 긍정적인 양(+)의 계수 값으로 나 타나고 있고, $\mathrm{p}$ 값이 .008로 $95 \%$ 신뢰수준에서 매 우 유의한 값을 나타냈다. 따라서 '기내 서비스케 이프 항목 중 물리적 서비스 환경은 승무원의 서 비스 지향성에 정(+)의 영향을 미친다' 라는 가 설 2-1은 실증 결과 채택되었다.

Table 5 가설검증 (종속변수 : 서비스 제공행동)

\begin{tabular}{|c|c|c|c|c|c|}
\hline $\begin{array}{l}\text { 종속 } \\
\text { 변수 }\end{array}$ & 독립변수 & Beta & $\begin{array}{l}\text { Std. } \\
\text { Beta }\end{array}$ & $\begin{array}{c}\mathrm{t}-\text { 값 } \\
\text { (p-값) }\end{array}$ & $\mathrm{VIF}$ \\
\hline \multirow{2}{*}{$\begin{array}{l}\text { 서비스 } \\
\text { 제 공 } \\
\text { 행 동 }\end{array}$} & 동기부여 & .432 & .431 & $\begin{array}{l}6.736 \\
(.000) \\
\end{array}$ & 1.00 \\
\hline & $\begin{array}{l}\text { 서비스 } \\
\text { 지향성 }\end{array}$ & .483 & .484 & $\begin{array}{l}8.813 \\
(.000)\end{array}$ & 1.42 \\
\hline $\begin{array}{l}\text { 종속 } \\
\text { 변수 }\end{array}$ & \multicolumn{5}{|c|}{$\begin{array}{l}\mathrm{DW}=1.547, \mathrm{~F}=136.116(\mathrm{p}=.000) \\
\text { Adj } \triangle R^{2}=.575\end{array}$} \\
\hline
\end{tabular}

<표 5>는 2개의 매개변수인 동기부여 및 서비 스지향성이 승무원의 서비스 제공행동에 미치는 영향력을 검증하기 위하여 다중회귀분석을 실시 하였다. 전체 모형적합도를 보여주는 $\mathrm{F}$-값이 $136.116(\mathrm{p}=.000)$ 로 매우 유의하게 나타났으므로 다중회귀분석을 위한 모델 설정은 매우 적합한 것으로 나타났다. 아울러 2 개의 독립변수들의 서 로 상관을 나타내는 다중공선성 계수들은 각각 $\mathrm{VIF}=1.000$ 이며 Durbin-Watson $=1.547$ 을 나타 내고 있어 변수들 간 다중공선성 위험성은 제거 된 것을 확인 할 수 있다. 다중회귀분석 결과를 살펴보면, 2 개의 독립변수들 모두 서비스 제공행 동에 유의한 영향을 미치는 변수로 분석되었다.

\section{IV. 결 론}

서비스케이프 항목이 승무원의 동기부여에 미 치는 영향력을 검증하기 위하여 서비스케이프 요 인 5 개를 독립변수로 하고 승무원의 동기부여를 종속변수로 하는 다중회귀분석을 실시하였는데 그 결과 5 개 요인 모두 승무원의 동기부여에 $95 \%$ 의 신뢰수준에서 유의한 정 $(+)$ 의 영향을 미 치는 것으로 조사되었다. 기내 서비스케이프 항 목이 서비스 지향성에 미치는 영향력을 검증하기 위하여 서비스케이프 요인 5개를 독립변수로 하 고 서비스 지향성을 종속변수로 하는 다중회귀분 석을 실시하였다. 본 연구의 연구모형에 따르면 승무원의 서비스 지향성 승무원의 동기부여와 자 발적 서비스와 더불어 종속변수인 승무원의 서비 스 제공행동에 영향을 미치는 매개변수의 역할을 한다. 마지막으로 기내 서비스케이프 항목이 자 발적 서비스에 미치는 영향력을 검증한 결과 서 비스 심미성, 청결성 및 물리적 서비스 환경만이 승무원의 자발적 서비스에 정 $(+)$ 의 영향을 미치 는 것으로 조사되었다. 서비스 매뉴얼은 비록 서 비스 지향성과 승무원의 동기부여에 긍정적인 영 향을 미치지만 승무원의 자발적 서비스 제공에는 유의한 영향이 없는 것으로 분석되었다.

실증분석 결과 중 서비스 매뉴얼의 융통성 부 족이 승무원의 자발적 서비스 제공 의도 증진에 유의한 영향을 미치지 못하는 원인에 대한 추가 적인 설명은 다음과 같다. 서비스 매뉴얼이란 사 내의 일반화된 근무기준으로 $\mathrm{A}$-항공사 승무원들 은 신입사원으로서 최초 교육 시 서비스 매뉴얼 을 접하게 되고 이를 익힌다. 즉, 서비스 매뉴얼 로 서비스 제공 경험이 없는 승무원에게 서비스 숙련자들이 마련한 일반화된 경험의 주입이라고 도 할 수 있을 것이다.

최근 들어 승객들의 서비스 니즈가 높아가고 서비스 기대 수준이 급상승하면서 기내에서 제공 되는 기내 서비스의 본질은 유형의 서비스 보다 는 무형의 서비스 제공 비중이 더욱 중요 시 되 어가고 있다. 특히 현재 시대에 서비스와 함께하 는 수단의 목적 또한 당연시 되고 있다. 예컨대 승객들은 비행기를 타고 가는 이동의 목적, 식음 료 제공이 목적을 넘어 당연한 권리형 서비스라 고 인식하고 있다.

이 또한 항공사의 서비스 최접점에서 서비스를 제공하고 있는 승무원들이 공감하고 있다. 그러 나 서비스 현장인 기내에서 서비스 제공자 즉, 
승무원들은 회사의 서비스 목표 또한 고객의 니 즈에 맞추어 발전 및 변화하는 지에 대한 판단이 확실치 않은 경우가 종종 있다. 회사의 서비스 목표와 달리 서비스 접점의 승무원들에게 요구하 는 서비스의 내용과 형태가 더욱 복잡 - 다양화되 어지고 있다. 무형적인 고차원적 서비스와 정형 화된 서비스 매뉴얼의 차이 때문에 원래의 서비 스 매뉴얼의 취지인 승무원의 탄력적인 서비스 대처능력과 자발적인 서비스 제공의도가 아닌 서 비스 매뉴얼의 프레임 속에서 기내 서비스 제공 이 다소 제한되는 상황이 종종 발생하곤 한다. 상용고객에 대한 탑승감사 인사를 처음 시도했을 때는 매우 신선하고 고객들로부터 좋은 서비스 만족도 반응을 받은 바 있다. 따라서 이를 탑승 감사 인사를 하면 좋겠다고 판단한 회사는 이 내 용을 서비스 매뉴얼로 작업화 하였는데 그 결과 서비스 매뉴얼대로만 행하는 일련의 제공행동으 로 탑승감사 인사가 되었고 이렇게 형식적인 인 사는 고객들에게도 더 이상의 큰 서비스 만족도 증진을 불러일으키지 못하게 되었으며 가끔 성 의 없는 인사로 인해 잠재상용고객에게까지 서비 스 불만이 발생되는 결과를 낳았다. 따라서 서비 스 매뉴얼화로는 완성할 수 없는 무형의 서비스 본질은 순간순간 승무원들이 대처해야하는 유동 적인 것이라는 것을 인식하여야 할 것이다.

\section{참 고 문 헌}

[1] 유정남·이영재·이용기, "호텔기업의 서비스지 향성이 종업원만족에 미치는 영향, 등급별 분석 을 중심으로", 관광학연구, (2000), 23(2), 138-155. [2] Baker, J., Levy, M.\& Grewal, D. "An experimental approach to marking retail store environmental decision". Journal of Retailing, (1992), 68(4), 445-460.

[3] Baker, J., Grewel, D. and Parasuraman, A., "The influence of fashion store environment on quality inferences and store image", Journal of the Academy of Marketing Sciences, (1994), 22(4), 328-339.

[4] Beatty, E. E. and Schneider, C. E. "Personnel administration : An experimental skill building approach", (1981), Addison-Wesley Publishing, 2nd Edition, N. Y. [5] Bitner, M. J. "Servicescapes : The impact of physical surroundings on customers and employees", Journal of Marketing, (1992), 56(4), 57-71.

[6] H. Maslow "A Theory of Human Behavior", Psychological Review, , (1943), Vol 50(4), 370-396

[7] Koepp, S., "Pul-eez! Will Someone Help Me?", TIME, (1987), Feb(2), 28-34.

[8] Normann, R. "Service Management: Strategy and Leadership in Service Business", (1991) Wiley, 2nd Edition.

[9] Parasuraman, A., Valarie A. Zeithamal, and Leonard L. Berry "A Conceptual Model of Service Quality and Its Implications for Further RESEARCH," Journal of Marketing, (1985), 49(Fall), 41-50.

[10] Schmenner, Roger W., "How Can Service Businesses Survive and Prosper?" Sloan Management Review, (1986), 27(Spring), 21-32.

[11] Shostack, G. Lynn "Designing the Service Encounter", New York: Lexington Books, (1984) 243-254.

[12] Solomon, Micahel R., "Packaging the Service Provider," Services Industries Journal, (1985), 5(1), 64-71.

[13] Surprenant, Carol F. and Gilbert A. Churchill, Jr."Can Role-Playing Be Substituted for Actual Consumption?" in Advances in Consumer Research, Vol. 11, Thomas C. Kinner, ed. Ann Arbor, MI: Association for Consumer Research, (1984), 122-6.

[14] Zeithaml, Valarie, "Consumer Perceptions of Price, Quality, and Value: A Means-End Model and Synthesis of Evidence," Journal of Marketing, (1988), 52 (July), 2-22. 